UDC 378.147:378.22

DOI: $10.31470 / 2415-3729-2019-9-42-55$

\title{
Professional Training of Future Masters of Education in the Conditions of Dual Teaching
}

\section{Yuliia Bahno}

Doctor of Philosophy in Pedagogy (Ph.D), Associate Professor, Associate Professor of the Department of Pedagogy Pereiaslav-Khmelnytskyi Hryhorii Skovoroda State Pedagogical University, $\bigotimes$ 30, Sukhomlynskyi Str., Pereiaslav-Khmelnytskyi, Kyiv Region, Ukraine, 08401

E-mail: julijabaghno@gmail.com ORCID: 0000-0003-3513-6154

Date of receipt of the article: December 03, 2018 Article accepted for publication: February 22, 2019

\section{Професійна підготовка майбутніх магістрів освіти в умовах дуального навчання}

\section{Юлія Миколаївна Багно}

кандидат педагогічних наук, доцент, доцент кафедри педагогіки ДВНЗ «Переяслав-Хмельницький державний педагогічний університет імені Григорія Сковороди», $\bigotimes$ вул. Сухомлинського, 30, м. Переяслав-Хмельницький, Київська обл., Україна, 08401

Дата надходження статті: 03 грудня 2018 p. Стаття прийнята до друку: 22 лютого 2019 р.

\section{Abstract}

The current stage of development of higher education in Ukraine is characterized by a special intensity and scale of transformations, which envisage the formation of a holistic educational space based on the unification of national educational 
services markets, conditioned by globalization and integration processes.

The training of scientific-pedagogical and pedagogical workers of higher educational institutions is considered in this context as an important prerequisite that ensures the modernization of education. In these conditions, the renewal of the content of the Master of Education training is of particular importance, it will equip a future teacher with the skills to integrate special psychological-pedagogical, methodological and didactic knowledge in the conditions of professional activity. A guideline on this issue is that European standards and recommendations for graduate students are formulated in the Dublin Descriptors and the European Qualification Framework.

These European benchmarks, as well as the expansion of academic freedoms, changing educational paradigms require a fundamentally new content, methods and forms of the Master of Education training, the purpose of which is to shape the personality of a student as a teacher and professional of an institution of higher education who is able to independently and creatively think and act.

The staff of the department of pedagogics of PereiaslavKhmelnytskyi Hryhorii Skovoroda State Pedagogical University developed the concept of educational activities in the specialty 011 Educational, pedagogical sciences, fields of knowledge 01 Education / Pedagogy.

The concept provides for the formation of masters of education integrated competence, general and professional competencies. The development of these competencies will be facilitated by the introduction of a dual form of higher education. The dual form of getting higher education is a way of getting an education; it provides for a combination of training of applicants of higher education in institutions of higher education with training in workplaces in institutions, organizations and enterprises for obtaining certain qualifications, usually on the basis of a contract, with the performance of official duties.

The high level of the Master of Education professional training in the conditions of the dual form of education is possible due to the mastering of the basics of the professional teaching 
activity of the teacher of the institution of higher education in real conditions; application of modern educational technologies of practical activity; the methodological readiness of a master of education to implement the educational process in institutions of higher education.

Key words: master of education, dual education, higher education institutions, modernization of education, methods and forms of education, modern learning technologies, variability, individualization and differentiation of education.

\section{References}

1. Dublin Descriptors. Retrieved from http: //www.tcd.ie/ teaching-learning/ academic-development/assets/ pdf/ dublin_descriptors.pdf

2. The European Qualifications Framework for Lifelong Learning (2008). Luxembourg : Office for Official Publications of the European Communities. Retrieved from https://ec.europa.eu/ploteus/search/site

3. Vitvytska, S.S. (2016). Teoretychni i metodychni zasady pedahohichnoi pidhotovky mahistriv $\mathrm{V}$ umovakh stupenevoi osvity [Theoretical and methodical principles of pedagogical preparation of masters in conditions of graduate education]. In O.A. Dubaseniuk (Ed.), Akmedosiahnennia naukovtsiv Zhytomyrskoi naukovopedahohichnoi shkoly [Acme of the scientists of Zhytomyr scientific and pedagogical school] (p. 302-347). Zhytomyr: ZhDU im. I. Franka [in Ukrainian].

4. Zhyhir, V.I. (2012). Indyvidualizatsiia profesiinoho navchannia menedzheriv osvity u VNZ [Individualization of education managers' professional training in higher educational institutions]. Visnyk Zaporizkoho natsionalnoho universytetu, 2(18), 107-113. Retrieved from http://web.znu.edu.ua [in Ukrainian].

5. Mazur, V.A. (2018). Perspektyvy ta problemy vprovadzhennia dualnoi osvity v Ukraini [Prospects and problems of the dual education implementation in Ukraine]. Profesiina pidhotovka fakhivtsia v konteksti potreb suchasnoho rynku pratsi : materialy III Vseukr. nauk.-prakt. internet-konf. (pp.3-7). Vinnysia [in Ukrainian]. 
6. Myronchuk, N.M. (2015). Osoblyvosti pratsi vykladacha vyshchoho navchalnoho zakladu v konteksti samoorhanizatsii yoho profesiinoi diialnosti [Peculiarities of the work of a higher educational institution teacher in the context of its professional activity self-organization]. Problemy osvity: Nauk-metod. zb., 85, 147-151. Retrieved from http://eprints.zu.edu.ua/19774/1/.pdf [in Ukrainian].

7. Protsenko, O.B. (2015). Profesiina pidhotovka vykladachiv vyshchoi shkoly v mahistraturi: dosvid yevropeiskykh krain [Professional training of higher education teachers in the magistracy: the experience of European countries]. Osvitolohichnyi dyskurs, 3 (11), 238-247. Retrieved from http://oaji.net/articles/2016/2923-1456478364.pdf [in Ukrainian].

8. Sidash, N.S. (2014). Suchasni problemy pidhotovky maibutnikh vykladachiv vyshchykh shkil v suchasnii vitchyznianii nautsi [Modern problems of preparing future higher schools teachers in modern native science]. Dukhovnist osobystosti: metodolohiia, teoriia i praktyka, 4 (63), 136-145. Retrieved from http://oaji.net/articles/2015/690-1437487825.pdf [in Ukrainian].

9. Iak reformuvatymut vyshchu osvitu Ukrainy: pidsumky zasidannia Kolehii MON. na temu: «Priorytetni napriamky zmin u vyshchii osviti na 2018-2019 rr.» [How will the higher education of Ukraine be reformed: the results of the meeting of the Collegium of the Ministry of Education and Science. on the theme: «Priority directions of changes in higher education for 2018-2019 years») (26 sichnia 2018 r). [in Ukrainian].

\section{Вступ}

Сучасний етап розвитку вищої освіти в Україні характеризується особливою інтенсивністю та масштабами перетворень, що передбачають формування цілісного освітнього простору на основі об'єднання національних ринків освітніх послуг, зумовлені глобалізаційними та інтеграційними процесами. 
Різні аспекти підготовки магістрів у ЗВО є об'єктом досліджень сучасних українських та зарубіжних учених, зокрема Н. Авшенюк, В. Андрущенка, С. Вітвицької, С. Дворецького, Л. Козак, В. Козакова, В. Кременя, Ю. Красильника, В.Лащихіна, В. Лугового, І. Мигович, Н. Ничкало, Л. Пуховської, О. Самойленко, А. Сбруєвої, О. Спіріна, Т.Сущенко, А. Роляк та інші. Праці науковців присвячені аналізу систем педагогічної освіти Свропейських країн, розкриттю проблем філософії освіти, обгрунтуванню нових підходів розбудови та вдосконалення системи професійної підготовки магістрів, формування компетентностей, підвищення якості вищої освіти.

Мета статті - визначити особливості підготовки магістрів освіти в умовах дуального навчання. У процесі дослідження були поставлені такі завдання: охарактеризувати сучасні тенденції розвитку вищої освіти відповідно до євроінтеграційних процесів; визначити особливості впровадження у практику роботи закладів вищої освіти дуальної форми здобуття вищої освіти.

\section{Матеріал і методи досліджень}

Відповідно до мети та визначених завдань добиралися методи дослідження, зокрема, теоретичні (аналіз та узагальнення науково-педагогічної літератури та нормативно-правових матеріалів).

\section{Результати та їх обговорення}

3 метою підвищення якості вищої освіти в Україні Л. Гриневич виокремила головні завдання для ЗВО на 20182019 роки:

- розбудову внутрішніх систем забезпечення якості відповідно до вимог європейських стандартів та рекомендацій;

- модернізацію змісту освіти і структури освітніх програм, приведення їх у відповідність до нових стандартів вищої освіти;

- дебюрократизацію на рівні закладу вищої освіти;

- неухильне дотримання визначених новим Законом України «Про освіту» вимог до академічної доброчесності; 
- зрушення у підготовці наукових кадрів, зокрема, у вимогах до дисертацій на здобуття наукових ступенів (Як реформуватимуть вищу освіту України: підсумки засідання Колегії МОН).

Підготовка науково-педагогічних і педагогічних працівників закладів вищої освіти розглядається у цьому контексті як важлива передумова, що забезпечує проведення модернізації освіти. За цих умов особливого значення набуває оновлення змісту підготовки магістра освіти, що озброїть майбутнього викладача вміннями інтегрувати спеціальні, психолого-педагогічні, методичні й дидактичні знання в умовах професійної діяльності. Орієнтиром у цьому питанні виступають Свропейські стандарти та рекомендації до випускників магістратури сформульовані у «Дублінських дескрипторах» (Dublin Descriptors) та «Свропейській системі кваліфікацій» (European Qualification Framework). Так «Дублінськими дескрипторами» окреслені наступні вимоги:

- застосування знань та вмінь вирішувати нові нестандартні ситуації;

- володіти комунікативними здібностями;

- мати навички, які дозволяють продовжувати освіту (Dublin Descriptors).

- Разом 3 тим «Європейська система кваліфікацій», зазнає, що випускники повинні вміти:

- використовувати теоретичні та практичні знання для розвитку оригінальних ідей;

- досліджувати стан проблем шляхом інтегрування знань 3 нових областей та знаходити рішення в умовах неповної та обмеженої інформації;

- демонструвати лідерство та інновації в роботі;

- демонструвати здатність до оперативної взаємодії в складних ситуаціях;

- нести соціальну, наукову та етичну відповідальність, яка виникає у роботі (The European Qualifications Framework for Lifelong Learning, 2008).

Законом України «Про вищу освіту» (2014р.) визначено, що магістр це освітній ступінь, що здобувається на другому рівні вищої освіти та присуджується вищим 
навчальним закладом у результаті успішного виконання здобувачем вищої освіти відповідної освітньої програми. Магістерський рівень вищої освіти передбачає здобуття особою поглиблених теоретичних та/або практичних знань, умінь, навичок за обраною спеціальністю, загальних засад методології наукової та/або професійної діяльності (Закон України «Про вищу освіту» 2014 р.).

H. Мирончук окреслено вектори професійної діяльності викладача вищої школи: 1) навчально-педагогічна діяльність (викладання); 2) методична діяльність; 3) організаційна робота; 4) виховна робота; 5) наукова діяльність; 6) громадсько-педагогічна діяльність (профспілкове членство, участь у громадських об'єднаннях, самоврядуванні, волонтерство, громадські доручення); 7) академічна мобільність (викладання в інших навчальних закладах; читання лекцій для різних категорій педагогічних працівників; викладання в закордонних навчальних закладах); 8) стажування; 9) аналітико-оцінна діяльність (критичне осмислення власної професійної діяльності, аналіз iii ефективності; надання звітності щодо різних видів виконуваної діяльності); 10) професійне самоудосконалення (самоосвіта, самовиховання, саморозвиток) (Мирончук, 2015).

На думку С. Вітвицької до основних компетентностей та компетенцій, якими мають оволодіти магістри освіти належать: психологічна (інформаційно-психологічна, комунікативна, перцептивна); педагогічна (інформаційнопедагогічна, операційно-пошукова, креативна, контрольно-оцінна, організаторська, технологічна); фахова (інформаційно-предметна, регулятивно-коригуюча, методична (дидактична, мовленнєва, процесуальна, дослідницько-пошукова); соціальна (моральна, правова, загальнокультурна, світоглядна, комунікативна); життєва (адаптивна, деонтологічна, життєтворча) (Вітвицька, 2016).

Означені європейські орієнтири, а також розширення академічних свобод, зміна освітніх парадигм потребує принципово нового змісту, методів і форм підготовки 
магістра освіти, метою якої є формування особистості студента як педагога-професіонала закладу вищої освіти, здатного самостійно і креативно мислити і діяти.

Колективом кафедри педагогіки ДВНЗ «ПереяславХмельницький державний педагогічний університет імені Григорія Сковороди» розроблена концепція освітньої діяльності за спеціальністю 011 Освітні, педагогічні науки, галузі знань 01 Освіта/Педагогіка. Основні засади цієї концепції відповідають основним положенням Конституції України, Національної доктрини розвитку освіти, законів України «Про освіту», «Про вищу освіту», «Про загальну середню освіту», «Про професійно-технічну освіту», Постанови Кабінету Міністрів України від 23.11.2011 № 1341 «Про затвердження Національної рамки кваліфікацій», наказами Міністерства освіти і науки України, іншими нормативно-правовими актами у сфері освіти, документами Болонського процесу, Статутом ДВНЗ «ПереяславХмельницький державний педагогічний університет імені Григорія Сковороди», Положенням про організацію освітнього процесу Університету, Правилами внутрішнього розпорядку Університету.

Концепція передбачає формування у магістрів освіти інтегральної компетентності, загальних та професійних компетентностей. Інтегральна компетентність, розглядається як здатність розв'язувати складні професійні завдання, що передбачає викладацьку, дослідницьку, інноваційну діяльність у динамічних умовах закладу вищої освіти.

Загальні компетентності, полягають у здатності застосовувати знання в практичних ситуаціях; знаннях та розумінні предметної галузі та розуміння професії; здатності проведення досліджень на відповідному рівні; здатності до пошуку, оброблення та аналізу інформації з різних джерел; здатності до адаптації та дії в новій ситуації; здатності генерувати нові ідеї (креативність); здатності виявляти, ставити та вирішувати проблеми; навичок міжособистісної взаємодії; здатності працювати автономно і в міжнародному контексті, володіння усною й письмовою рідною та іноземною мовами; здатності розробляти та управляти 
проектами; здатності до рефлексії в процесі розв’язання професійних завдань; здатності до самоосвіти і професійного самовдосконалення; здатності

реалізовувати здоров'язбережувальний підхід в організації освітнього процесу.

Фахові компетентності вбачаємо в здатності розуміти філософські засади освіти, сучасні методологічні підходи до організації освіти; здатності визначати педагогічні цінності та сприяти їх формуванню у вищій школі; здатності застосовувати інформаційно-комунікаційні технології в освітньому процесі; здатності орієнтуватись у сучасній нормативно-правовій базі розвитку освіти, тенденціях освітньої політики в Україні та світі; здатності адекватно застосовувати методи науково-педагогічного дослідження; вміння планувати, організовувати власну науковопедагогічну діяльність; здатності розглядати педагогічні явища, розвиток освіти і науки в їх суспільно-економічній зумовленості та історичній ретроспективі; застосовувати компаративний аналіз щодо вивчення педагогічних проблем у зарубіжному та вітчизняному контекстах; здатності адаптувати та впроваджувати ідеї видатних українських та зарубіжних педагогів у сучасну педагогічну практику; здатності до забезпечення освітнього процесу вищої школи навчально-методичними i програмними матеріалами; здатності проектувати і реалізовувати зміст вищої освіти, визначати індивідуальні освітні проекти, моделювати освітні процеси і системи; здатності володіти знаннями про закономірності філогенезу та онтогенезу людини на різних вікових етапах, про розвиток психічних процесів людини, враховувати ці закономірності в освітньому процесі; здатності застосовувати інноваційні педагогічні технології; прогнозувати розвиток і використання сучасних технологій навчання і виховання; здатності ефективно використовувати сучасні методи, форми, засоби навчання у вищій школі; здатності до самоаналізу своїх вчинків на засадах етичної культури; уникнення порушень норм професійної моралі; розробки алгоритму індивідуальної педагогічної взаємодії на етичній основі; здатності усвідомлювати гендерні 
особливості людей, співпрацювати з різними людьми в соціумі.

На думку О. Проценко, щоб отримувати високу результативність навчання студентів, викладачам необхідно використовувати відповідні оптимальні методи та форми навчання, включаючи i новітні технології, розвивати незалежний творчий підхід до викладання між педагогічною теорією, науковими дослідженнями та власним педагогічним досвідом, проводити власні дослідження та втілювати їх у практику (Проценко, 2015).

На нашу думку, у цьому питанні сприятиме впровадження дуальної форми здобуття вищої освіти. Дуальна форма здобуття вищої освіти - це спосіб здобуття освіти, що передбачає поєднання навчання здобувачів вищої освіти у закладах вищої освіти 3 навчанням на робочих місцях в установах, організаціях та підприємствах для набуття певної кваліфікації, як правило на основі договору, 3 виконанням посадових обов'язків.

Означені вище заходи будуть ефективними завдяки підвищенню якості освіти за рахунок адаптації освітніх програм до вимог роботодавців; розширенню можливостей для прикладних наукових досліджень; розширенню можливостей для підвищення кваліфікації викладацького складу.

Дуальна форма освіти, на переконання В. Вем'ян, В. Тер-Ованес'ян, на ранніх стадіях навчання забезпечує набуття студентами цільової підготовки, певних професійних компетенцій, а також таких особистісних якостей, як уміння працювати в команді, навичок оптимального вибору технологічного рішення, відповідальності за доручену ділянку діяльності.

До переваг дуальної професійної освіти, на думку С. Кирилюк, належать:

Практична орієнтація навчального процесу. Завдяки такій спрямованості навчання підготовка майбутніх фахівців більшою мірою сконцентрована на формуванні й розвитку фахових умінь і навичок, ніж традиційна професійна освіта. Крім того, розвиваються так звані «ключові компетенції», зокрема, уміння працювати в команді, організовувати 
професійну діяльність, співпрацювати 3 колегами, спілкуватися з клієнтами тощо.

Інтенсифікація професійної освіти. Інтеграція практичної професійної підготовки у навчальний процес пришвидшує отримання бажаного диплома у порівнянні 3 традиційним шляхом - спочатку практична підготовка, а потім навчання у вищому навчальному закладі освіти (Мазур, 2018: 3-7).

Високий рівень професійної підготовки магістра освіти в умовах дуальної форми навчання є можливим завдяки засвоєнню основ професійної педагогічної діяльності викладача закладу вищої освітив реальних умовах; застосуванню сучасних освітніх технологій практичної діяльності; методичній готовності магістра освіти до здійснення освітнього процесу в закладах вищої освіти.

Упровадження дуальної форми навчання у процес підготовки магістрів освіти націлено на вирішення наступних завдань:

- адаптація професійних знань, умінь, навичок випускників до мінливих умов праці;

- поліпшення практичної готовності магістрів до професійної педагогічної діяльності;

- посилення кадрового складу закладів вищої освіти молодими фахівцями;

- створення конкурентного середовища серед студентів, що забезпечує зростання успішності та мотивації;

- підвищення кваліфікації науково-педагогічних кадрів за рахунок стажувань.

Основними принципами, що лежать в основі дуальної освіти, є принцип варіативності, індивідуалізації та диференціації.

В. Жигірь зазначає, що принцип варіативності вимагає: визначення в навчальній програмі обов'язкових видів, форм роботи та форм перевірки знань магістрів, що передбачає добровільний вибір ними, хто навчається, темпів навчання, оптимальних засобів навчання, урахування умов навчання, їх навчальних можливостей та подальших перспектив; розробки методичних матеріалів завдань та практичних занять і необхідної звітної документації з урахуванням 
професійних інтересів, рівня їх індивідуальних здібностей та подальшого професійного зростання магістра; стимулювання творчої активності та дослідницької діяльності магістрів (Жигірь, 2012: 111).

\section{Висновки}

У системі дуальної форми здобуття вищої освіти магістрами освіти індивідуалізація навчання передбачає можливість обрання індивідуальної траєкторії навчання, вибору рівня і методів оволодіння змістом навчання. За таких умов навчання передбачає диференціацію не лише обсягу, складності або строків виконання завдань, а й міру та характер допомоги викладача в кожному окремому випадку. Перевагою $є$ практична реалізація теоретичних знань, удосконалення знань у процесі практики за допомогою підготовлених допоміжних матеріалів у вигляді планів, конспектів, схем дій, презентацій.

До переваг дуальної форми здобуття вищої освіти можемо віднести формування й розвиток фахових умінь $\mathrm{i}$ навичок; формування інтегральної, загальних та фахових компетентностей; варіативність, індивідуалізація та диференціація навчання.

\section{Література}

1. Dublin Descriptors [Electronic resource]. Mode of access : URL: $\quad$ http://www.tcd.ie/teaching-learning/academicdevelopment/assets/pdf/dublin_descriptors.pdf.

2. The European Qualifications Framework for Lifelong Learning Luxembourg : Office for Official Publications of the European Communities, 2008. 10 pp. URL: https://ec.europa.eu/ploteus/search/site.

3. Вітвицька С. С. Теоретичні і методичні засади педагогічної підготовки магістрів в умовах ступеневої освіти. Акмедосягнення науковців Житомирської науковопедагогічної школи: монографія. За ред. О.А. Дубасенюк. Житомир : Вид-во ЖДУ ім. І. Франка, 2016. С. 302-347.

4. Жигірь В. І. Індивідуалізація професійного навчання менеджерів освіти у ВНЗ. Вісник Запорізького національного університету. 2012. № 2(18). С.107-113. URL: http://web.znu.edu.ua. 
5. Мазур В. А. Перспективи та проблеми впровадження дуальної освіти в Україні. Професійна підготовка фахівия в контексті потреб сучасного ринку праці : матеріали III Всеукр. наук.-практ. інтернет-конф., 27 лют. 2018 р. м. Вінниця, 2018. С.3-7.

6. Мирончук Н. М. Особливості праці викладача вищого навчального закладу в контексті самоорганізації його професійної діяльності. Проблеми освіти: наук-метод. зб. Вип. 85. 2015. С.147-151. URL: http://eprints.zu.edu.ua/19774/1/.pdf.

7. Проценко О. Б. Професійна підготовка викладачів вищої школи в магістратурі: досвід європейських країн. Освітологічний дискурс. 2015. № 3(11). с.238-247. URL :http://oaji.net/articles/2016/2923-1456478364.pdf.

8. Сідаш Н. С. Сучасні проблеми підготовки майбутніх викладачів вищих шкіл в сучасній вітчизняній науці. Духовність особистості: методологія, теорія $i$ практика. 2014. 4 (63). C. 136-145. URL: http://oaji.net/articles/2015/690-1437487825.pdf.

9. Як реформуватимуть вищу освіту України: підсумки засідання Колегії МОН. на тему: «Пріоритетні напрямки змін у вищій освіті на 2018-2019 рр.» (26 січня 2018 p). URL: https://eenu.edu.ua/uk.

\section{Багно Ю. М.}

\section{Професійна підготовка майбутніх магістрів освіти в умовах дуального навчання}

\section{Анотація}

Підготовка науково-педагогічних і педагогічних працівників закладів вищої освіти розглядається як важлива передумова, що забезпечує модернізацію освіти. Свропейські орієнтири, а також розширення академічних свобод, зміна освітніх парадигм вимагають принципово нового змісту, методів і форм підготовки магістрів освіти, метою яких $є$ формування особистості викладача-професіонала. Високий рівень професійної підготовки магістра можливий завдяки 
впровадженню дуальної форми, що сприяє засвоєнню основ професійної педагогічної діяльності в закладах вищої освіти в реальних умовах; застосуванню сучасних навчальних технологій практичної діяльності; формуванню професійної готовності магістра освіти до реалізації навчального процесу в закладах вищої освіти.

Ключові слова. Магістр освіти, дуальна освіта, заклади вищої освіти, модернізація освіти, методи та форми навчання, сучасні технології навчання, варіативність, індивідуалізація та диференціація навчання.

\section{Багно Ю.Н.}

\section{Профессиональная подготовка будущих мастеров образования в условиях двойного обучения}

\section{Аннотация}

Подготовка научно-педагогических и педагогических работников заведений высшего образования рассматривается как важная предпосылка модернизации образования. Европейские ориентиры, а также расширение академических свобод, изменение образовательных парадигм требуют принципиально нового содержания, методов и форм подготовки магистров образования, целью которых является формирование личности преподавателя-профессионала. Высокий уровень профессиональной подготовки магистра возможен благодаря внедрению дуальной формы обучения, что способствует усвоению основ профессиональной педагогической деятельности в учреждениях высшего образования в реальных условиях; применению современных учебных технологий практической деятельности; формированию профессиональной подготовки магистра образования к реализации учебного процесса в учреждениях высшего образования.

Ключевые слова. Магистр образования, дуальная образование, высшие учебные заведения, модернизация образования, методы и формы обучения, современные технологии обучения, вариативность, индивидуализация и дифференциация обучения. 